\title{
Empowering Wakaf (Islamic endowment) for Economic Development: An Insightful Value of Nazir Waqf in Indonesia
}

\author{
Duski Ibrahima ${ }^{a}$ Ahmad Zainuria ${ }^{a}$ Miftachul Hudab \\ aProgram Pascasarjana,Universitas Islam Negeri Raden Fatah, Palembang, Indonesia \\ ${ }^{b}$ Academy of Islamic Civilization, Faculty of Social Science and Humanities, Universiti Teknologi Malaysia, 81310 \\ UTM Johor Bahru, Johor \\ *Corresponding author:duski_uin@radenfatah.ac.id
}

\author{
Article history \\ Received: 2019-11-12 Received in revised form: 2019-01-30 Accepted: 2019-01-31 Published online: 2020-02-29
}

\begin{abstract}
Productive waqf, which are one of the instruments of economic development for the people in Indonesia, have not yet materialized. Even though the legislation regarding waqf (Islamic endowment) has been ratified and enforced by the Indonesian Government, especially Law No. 1 of 2004 concerning Endowments. The main cause is assumed to lie in the end of waqf that has not been effective. Therefore, this study is focused on talking about Nazir (appointed administrator) under the position in managing productive waqf. The qualitative data used is sourced from books and statutory regulations on waqf in Indonesia, then analyzed by the opinions ulama especially those related to Nazir waqf, whether individuals, organizations or legal entities. Based on the studies conducted, the development of waqf is still a lot of obstacles or obstacles, such as the community's understanding of waqf is still weak, public trust in Nazir is still not lacking, and Nazir itself is still a lot of professionals. Therefore, the solution is to develop Nazir waqf, both moral, managerial, business knowledge, and raising Nazir that is not yet a full timer, not just part time work. When such obstacles have been overcome, God willing, productive endowments will develop in Indonesia, and finally the productive endowments can truly be an element of empowerment and economic development of the people.
\end{abstract}

Keywords: Productive Waqf, ummah (Islamic community) based-economy, and Nazir (appointed administrator) 


\subsection{INTRODUCTION}

Nazir's position is very important in the management of waqf, especially productive waqf, in an effort to prosper the community. Without Nazir, waqf will not develop properly. Endowments in the Islamic world, including in Indonesia, are one of the instruments for the development and economic empowerment of the ummah, in addition to other instruments. The use of the term economic ummah is intended because waqf can be carried out and used by the ummah in general, not only Muslims but also non-Muslims.

The term economic community in this context refers to a concept, thought, behavior or activity about the economy that is oriented to the welfare of the people in general, a mission desired by every teaching, including the teachings of Islam that rahmatan lil amin alamin. Therefore, the economy of the people is basically the same as the Islamic economy, but the discussion now is mainly on the issue of waqf. Muhammad Daud Ali defines Islamic economics with a collection of general economic foundations which are inferred from the Qur'an and Sunnah which have to do with economic affairs (Daud Ali, 1988: 3). Muhammad stated that with a simple expression, Islamic economics is an economic activity and its arrangement is in accordance with the principles of Islam and its economic principles (Al-Fanjari, 1988: 12).

There are several ways that Muslims can do, including in Indonesia, to develop and improve the economy of the people. The methods referred to, among others, are as follows: First, with istikhrajiyah work (exploring natural resources, such as agriculture, mining, solar power, air, water power). Second, by working at-tahwiliyah (converting raw materials into materials that are ready for consumption or use). Third, al-khidmat work (an activity aimed at helping others for personal needs), such as domestic help, scissors; or for general needs, such as road sweepers, park officials, traders, etc. (Qal'ah Ji, 2000: 36).

In addition to the above methods, there are more media or instruments that are very effective in the economic development of the ummah if managed properly by professional managers, who in waqf studies are called Nazir Wakaf, especially productive waqf. However, until now productive wagf in Indonesia has not been well developed. Why does something like this happen, is not regulation or legislation regarding waqf appearing and endorsed by the Government of Indonesia, namely Law Number 41 of 2004 concerning Endowments and Government Regulation No. 42 of 2006 concerning the Implementation of the Waqf Law. Not only that, the Indonesian $W$ aqf Agency has also been formed to coordinate waqf management in Indonesia. The author's assumption, that the main cause is the Nazir factor that has not been effective. What is the presence of Nazir in managing productive waqf in Indonesia?

\subsection{LITERATURE REVIEW}

\subsection{Concept of Waqf in Fiqh (Islamic Jurisprudence) Perspective}

According to Islamic jurisprudents, there is a concept of infaq which is very worthy of attention in the context of the development and economic empowerment of the ummah, namely endowments, including productive endowments, which will be the focus of our discussion. In linguistic terms, waqf means holding (al-habs), which is holding back in the sense that there is no transfer of property rights. Whereas in terms of meaning or according to the terms of the scholars, as stated by Wahbah az-Zuhaili, at least three tendency definitions are found, which contain different consequences, namely the definition proposed by Imam Abu Hanifa, the definition of 
the Shafi'i cleric and some Abu Hanifah students, definitions of scholars Malikiyah (Az-Zuhaili, 1989. 8: 153-158; Ibrahim, 2008: 37-40), which is briefly stated in the description below.

According to Imam Abu Hanifah, endowments are holding back property that legally remains the property of wakif and provides benefits for the purposes of goodness. From this definition, it is understood that: the property that has been represented is not lost from the ownership of Wakif, it remains its property. The benefits are benefits. Then, Wakif can withdraw the assets that have been represented and can sell it. When wakif dies, the waqf property can become an inheritance. This view of Imam Abu Hanifah does not seem to be in line with the hadith that says that waqf assets cannot be sold. Therefore, among the Hanafiyah themselves this opinion was corrected by the students of Imam Abu Hanifah. Abu Yusuf, for example, said that if Abu Hanifa had received the hadith of history 'Umar who did not allow to sell the waqf property, surely he would withdraw his opinion. (ash-Shan'ani, t.t. 3: 88).

According to the Syafi'iyah scholars, a number of students from Imam Abu Hanifah and Hanabilah scholars formulated that waqf is to retain property that may be utilized as well as eternal property (baqa' 'ainih) by discontinuing the right to tasharruf it for corrupt purposes, or distributing the benefits for good in order to draw closer to God. This definition implies that the waqf property must be a long-lasting substance, not one that is quickly damaged or depleted. Then, the property that has been represented, is no longer the property of wakif, and does not belong to someone else, but has moved to belong to Allah. Not only that, giving away the treasure is for ever, not only for a certain time. Another consequence, waqf is the act of holding back assets that can be used without being used up instantly, to distribute the results to something that is changed in order to get closer to Allah.

In the Maliki School of Religion it was also found a formula or formulation of waqf that was different from the formula above, even though there was indeed a meeting point. According to this school, endowments are holding back the assets of transacting, and giving away their benefits for the purposes of goodness, as a binding gift (tabarru 'prevalent) and objects remain the property of people who represent (waqif), and may for a certain time, not must be forever. This kind of definition, has the following consequences, namely the same as the opinion of Imam Abu Hanifah, that waqf property remains the property of people who represent (waqif). Then, different from the opinion of Imam Abu Hanifah and the same as the syafi'iyah and Hanabilah scholars, people who represent (waqif) may not tasharruf wakaf property, such as being sold, inherited or granted.

\subsection{Concept of Productive Waqf}

Talk about waqf does not only exist among the Muslim scholar, in the Indonesian government it has also been formulated well and systematically in the form of laws and government regulations. If we try to formulate the formulation of the scholars above to relate to the concept of waqf which has been formulated in the waqf law in force in Indonesia, it can be seen that in a country with a majority Muslim population a combination of various waqf concepts has been formulated by various scholars Flow.

This, for example, can be seen in the formulation of the definition of waqf. In the Act. No. 41/2004 concerning Endowments Article 1 (1) formulated that waqf is a legal act of wakif to separate and / give part of his property to be used forever or for a certain period of time in accordance with his interests for the purposes of worship and / or general welfare according to sharia. 
The definition in this law is very possible to make the waqf not only consumptive, but also productive. Productive $W$ aqf is intended as a property that has been represented by a person or entity that can bring results or profits by professional management, properly and correctly in accordance with shari'ah principles to be used for social purposes or purposes, in addition to the purpose of worship (Ibrahim, 2008: 66).

Historically, this endowment was only immovable objects and consumptive, such as land or land on which mosques and places of worship were erected. Then proceed to moving objects, such as vehicles, weapons or other war equipment. The longer the object of waqf develops, for example in the form of Al-Qur'an mushaf (manuscript), Hadith (Prophetic saying, acting and agreement) and other related books.

Along with developments and needs, the idea of revitalizing the Islamic economy was raised in Indonesia. In this context, the discourse was reappeared (now it has begun to be practiced) about productive endowments. There has been a shift from consumptive waqf to productive waqf. But, it should be stated that these two types of waqf, consumptive and productive, actually do have an accountable basis, along Islamic jurisprudence.

Regardless of that, according to article 43 paragraph (2) of the Act. No. 41/2004 Regarding Waqf, this productive endowment must be managed professionally. The management of productive endowments, including waqfland, can be managed for business land in accordance with sharia principles. Such management can be done to improve results or intensification (efforts to increase waqf land yield), both through extensification and diversification. Extensification is an effort to increase waqf land products by expanding land or waqf land. Diversification is an effort to increase the yield of waqf land by increasing the type of business on a waqf land. For example, on land (including land and building mosques), clinics, pharmacies, apartments, hospitals, restaurants, coffee shops etc. can be built. Waqf land can be managed for rubber plantations, oil palm, tents, fish farms, shrimp farms and expansion of existing waqf buildings for various productive functions.

In the explanation of article 43 of the Act. No. 41/2004 concerning Waqf is stated, that: Management and development of waqf property is carried out productively. His efforts, among others, are by collecting, investing, investing, production, partnerships, trade, agribusiness, mining, industry, technology development, apartments, flats, supermarkets, shops, offices, educational facilities, health facilities and businesses which is not contrary to sharia.

Productive waqf, as already mentioned, can also be in the form of movable objects, both nonmoney such as books (for example through the provision of reading parks that produce, according to sharia principles), or moving objects such as money waqf through investments in the mudharabah system, i.e. a cooperation transaction between two parties, capital owners and managers, to try to find profits and profits that will be divided according to agreement (alMarghinani, 2000. 3: 225; az-Zuhaili, 1997. 5: 3925). A Ala kulli things, productive endowments are endowments whose endowments are used to seek profits in accordance with sharia principles.

\subsection{Productive Waqf Designation}

In Islamic economics, the group has an obligation to distribute part of its wealth to the needypoor in order to move the people's economy. Islam has prepared a media for mobilizing the economy of the people in the form of infaq. The concept of infaq is general in nature, which can be understood from the example of the word of God in the Quran Surat al-Baqarah verse 261, 'the parable of those who infuse their wealth in the way of Allah is like a seed that grows seven 
stems, on each stalk there are one hundred seeds. Allah multiplies for whom He wills, and Allah is Extensive, Knowledgeable.'

The scholars have formulated the concept of infaq in detail and applicatively. Infaq means sharf al-mal ila al-hajah (providing or distributing property for a need or need). With this formula, it means that the concept of infaq, at least includes: Zakat, shadaqah, grants, gifts, blessings and endowments. Let's discuss one by one.

Zakat is defined by the act of giving a certain part of property to people who have the right to receive it with various terms and conditions. Grant: giving goods with no exchange and no cause (tamlik al-'ain if 'iwadh wa la sabab). Sadaqah: Giving goods because they expect merit in the hereafter. Prizes: give items because of glorifying. Livelihood: fulfilment of needs that apply according to circumstances and place. Reasons for living: For offspring, the cause of marriage, and the cause of ownership. Whereas the concept of waqf has been stated according to the scholars and according to the laws and regulations that apply in Indonesia.

Furthermore, in the waqf law it is explicitly stated about the use of productive waqf. It was stated, that the results of productive endowments can be utilized according to the designation stipulated by Wakif or, if not, according to Nazir. Article 22 of the Law. No. 41/2004 regulates that: In order to achieve the goals and functions of waqf, the waqf property can be allocated to: a. Facilities and activities of worship; b. Education and health facilities and activities; c. Assistance to the poor, neglected children, orphans, scholarships; d. Economic progress and improvement of the people; and / or e. Other general welfare advances that do not conflict with sharia and statutory regulations.

Not only that, the results of productive waqf can be used for natural disaster relief, floods, erupting mountain disasters, fire disasters and others. The results of productive endowments can also be utilized, in a numorous way, to meet the needs of managers or Nazir. The term ma'ruf is translated into the language of the law with 'not exceeding 10\% (ten percent) (Article 12 of Law $41 / 2004$ concerning Endowments). In addition, the benefits of productive waqf can be utilized for the maintenance and development of waqf property itself.

Even so, productive waqfin Indonesia, as mentioned, has not developed well. Our assumption, one of the main problems is related to the problem of Nazaf waqf. How is the position of Nazir waqf in Indonesia? What is Nazaf $W$ aqf? What are the duties and obligations of Nazaf Wakaf? What are the rights of Nazir waqf, along with the mandate that they carry out?

\subsection{METHODOLOGY}

This brief study or investigation is focused on in-depth talks about the existence of Nazir productive waqf in the management of waqf. As already mentioned, this endowment is one of the elements or instruments in the development and economic empowerment of the Ummah. The data that the author uses in this investigation is qualitative data, in the form of statements or expressions of scholars and experts in the field of waqf. While the source of this investigation is books that talk about waqf issues that have been written by experts in their fields. In other words, this study or investigation is a library research. Furthermore, because the focus of the discussion is the existence of the end of waqf and management of waqf in Indonesia, the data is also taken from sources in the form of Law No. 1 of 2004 concerning Waqfand Government Regulation on Endowments No. 42 of 2006 concerning the implementation of the $W a q f$, and other rules relating 
to waqf issues in Indonesia. Furthermore, the data is analyzed with various theories or opinions of experts that are relevant to waqf issues, especially those relating to Nazir waqf.

\subsection{ANALYSIS AND DISCUSSION}

\subsection{The existence of Productive Nazir Wakaf}

The presence of Nazir in waqf is very important, as important as 'amil in zakat. If 'amil zakat is a party or entity entrusted with the zakat property to be managed and distributed to the mustahiq, namely ashnaf ats-tsamaniyah, or eight groups of people who are entitled to receive zakat, as stated in the books of fiqh about zakat. In waqf problems, the manager is called Nazir or in the books of waqf fiqh often also called mutawalli. Although the urgency of Nazir and Amil is the same, the tasks of both are very different.

Nazir is an important element for managing waqf in the context of developing productive waqf as an instrument of community economic empowerment. That is, productive endowments will be realized as expected when managed by Nazir waqf who are economically sound. In other words, waqf can develop and be productive when managed by Nazir who has adequate abilities and competencies.

When someone wants to inherit his property, he surrenders property that is intended for endowments to certain people, as managers. The manager, in the books of jurisprudence, called Nazir or mutawalli and in the law is only called Nazir. He is in charge of maintaining, managing and developing the waqf property, by not being able to sell, grant or inherit it. While the benefits or results of the waqf assets are for certain people and certain fields in accordance with Islamic teachings.

When someone is inheriting his property, it will involve various elements as follows, namely: First, the party who accepts is called wakif. Second, the assets represented are called mauquf. Third, the party that receives the waqf property to be managed, which is called Narir. Fourth, waqf pledges are also called contract or shighah. Fifth, allocation of waqf assets. Sixth, the period of waqf.

It is seen that the Nazir is the party that receives the waqf property to be managed in accordance with the wishes of the person who represents (waqif). Nazir accepted the mandate to maintain or maintain waqf property, manage it, develop it, and distribute benefits or results to parties determined by waqif or determined by Nazir himself in developing the economic community.

Based on the description above, Nazir's existence is very important in the issue of waqf. Because, without the Nazir's endowments, waqf assets will not be managed, and cannot be developed and will not be able to become an instrument of development and economic empowerment of the people. Then, the success or failure of management and development of waqf assets is highly dependent on Nazir's abilities and competencies, as a manager. With Nazir like this, the waqf will develop well. The significance of Nazir's existence can also be seen from Nazir's concept, its duties and obligations as will be stated.

\subsection{The Nazir Concept And Its Variety}

The word Nazir is the Faith Faith of the Arabic word Nazhara-Yanzhuru-Nazhran Wa Nazhratan, which means: Observer, guardian, keeper, supervisor and manager. Nazir is interpreted Page $\mid 108$ 
as someone who is trusted by Wakif to pay attention to, maintain, maintain, supervise, manage and develop waqf property. In the jurisprudence literature, Nazir is often also called mutawalli.

There are a number of Nazir criteria that are expected to develop productive waqf, namely: First, have high moral integrity (siddiq, trust, tabligh, fathanah) with clear guidelines. Second, competent in carrying out the tasks of management and development of waqf property (al-ihtida 'ila tasharruf al-waqf wa tathawwurih) (al-Ghamarawi, t.t.: 307). Third, having expertise and skills in managing and developing waqf property that exceeds most people. Fourth, holding the principle of prioritizing the general interest of personal interests (al-mashlahah al-'ammah tuqaddam 'ala almashlahah al-khashshah).

In Law No. 41 of 2004 concerning Endowments mentioned, that: Nazir is a party that receives waqf property from wakif to be managed and developed in accordance with its designation. In the Indonesian context, the Nazir criteria have been formulated by classifying Nazir into several categories, as described in Law number 1 of 2004 with an explanation of the nature and forms of Nazir.

The kinds of Nazir, in accordance with Article 2 of Law Number 41 of 2004 concerning Endowments, include:

a. Naz̧ir Individual.

Nazir individual must be a group consisting of at least three people, and one of them was appointed as chairman of Nazir. This individual must be registered with the Minister of Religion and the Indonesian Waqf Agency through the local KUA.

The conditions for Nazir individuals are: Indonesian citizens, Muslim, adult, trustworthy, physically and spiritually capable, and not obstructed from carrying out legal actions.

b. Nazir organization

Nazir's organization, according to the provisions of Government Law No. 42 of 2006, is an organization engaged in the social, educational, social and / or religious fields of Islam established in accordance with the laws and regulations. Nazir's organization must also be registered with the Minister of Religion and the Indonesian Waqf Agency through the local Office of Religious Affairs (KUA).

The management of the organization which is the Nazirite must meet the requirements of Nazir individuals, Organizations: those engaged in the social, educational, social and / or religious fields of Islam.

c. Nazir is a legal entity

Nazir is a legal entity that is a legal entity that operates in the field of social, education, community and / or Islamic religion which is established in accordance with statutory regulations. Nazir must also be registered with the Minister of Religion and the Indonesian Waqf Agency through the local KUA.

Furthermore, the legal conditions of the legal entity are: The management of the legal entity concerned fulfills the requirements of the individual, an Indonesian legal entity established in accordance with the applicable laws and regulations; and legal entities: those engaged in the social, educational, social and / or religious fields of Islam. 


\subsubsection{Tasks and Obligations of Nazir}

The main tasks of Nazir, both individuals, organizations and legal entities, according to the provisions of Law No. 41 of 2004 concerning Waqf, are:

a. Administering waqf assets, for example managing waqf deed (AIW) and waqf certificates, making good and correct financial accounting for the management of waqf assets, and others.

b. Supervise, protect and maintain waqf property, for example taking care of waqf documents, and other related matters.

c. Manage and develop waqf property, according to its purpose, function and designation, either by managing it themselves or by involving other people or parties in the form of cooperation.

In addition to the above tasks, Nazir is also in charge of distributing the benefits or the results of waqf management to the parties wishing to, namely those who are entitled to receive benefits or results of waqf. This distribution can be done alone or by appointing other competent parties as suppliers. Therefore, Nazir must understand the laws of representation according to jurisprudence and according to the rules of law, especially concerning administration and accounting, regarding management of waqf assets, and also must have an entrepreneurial spirit.

Along with the above tasks, Nazaz waqf also has the following obligations, namely:

a. Must be registered with the Minister and Indonesian Waqf Agency.

b. Manage and develop waqf property in accordance with its purpose, function and designation.

c. Management and development of waqf property by Nazir is carried out in accordance with sharia principles.

d. Management and development of waqf property by Nazir is carried out productively.

e. In managing and floating waqf property, Nazir is prohibited from making changes to allotment of waqf property except on the basis of written permission from the Indonesian $W$ aqf Agency. Permits can only be granted if the waqf property cannot be used in accordance with the designation stated in the waqf pledge.

\subsubsection{Nazir Rights}

As a balance of the heavy tasks for these Nazis, both individuals, organizations and legal entities, both the fiqh and the waqf laws give them the rights, namely:

a. In the form of honorarium or intensive motivational nature. This honorarium is taken from the benefits of waqf management, not taken from the waqf assets it manages. This is different from the right for amil zakat, which can be taken from the assets of zakat itself.

Related to honararium or intensive Nazir, in a hadith mentioned, "It is not prohibited for the people who manage it to eat from the results of the management of waqf property in a manner that is numorous (H.R. al-Bukhari and an-Nasa ${ }^{\mathrm{i}}$ ).

Then in the formulation of the Act. No. 41/2004 Article 12 stated: Nazir can receive compensation from the net proceeds for the management and development of waqf property whose amount does not exceed 10\% (ten percent).

The existence of an honorarium or intensive is intended so that the management of waqf nutrients is carried out seriously, full timer, not casual work. In fact, today there are not many Nazirs who are full timers, as waqf managers.

b. In carrying out the task: Nazir obtained coaching from the Minister and the Indonesian Waqf Agency. 


\subsubsection{Nazir Service Period}

Based on government regulation number 2 of 2006, Nazir's term of service is limited to five years. After that, the service period can be extended by the Indonesian Waqf Agency if Nazir has carried out his duties properly and correctly.

In addition, Nazir can also be replaced, when it is concerned:

a. Died (for Naæir individuals)

b. Disband or dissolve in accordance with applicable laws and regulations (for Nazir organizations or legal entities)

c. On your own request, ask to be replaced

d. Do not carry out duties as Nazir

e. Violates the prohibition provisions in the management of waqf

f. Sentenced to a criminal sentence by a court that has permanent legal force.

It should be stated, that the dismissal and replacement of Nazir was carried out by BWI, Nazir, Wakaif and the community, should not unilaterally stop and replace Nazir in order to prevent conflicts in the community. BWI must listen to all parties involved before making a decision on dismissal and replacement.

\subsection{Problem and Solution}

Efforts to develop productive waqf, even though the waqf is an element of development and economic empowerment of the ummah, until now it seems that there are still many significant obstacles. For example: (1) Public understanding of waqf is still in the context of the books, has not shifted much to understanding in the context of the law, (2) Trust (trust) of the community towards Nazir (waqf manager) has not been as expected, (3) Complexities in the process of managing waqf are still often encountered by the public, especially by Nazir waqf.

In the context of the current discussion, a solution can be made, in addition to massive socialization of the importance of productive endowments, changing mindset or mindset about waqf, cooperation with parties related to waqf issues and management, the most important is continuous Nazir coaching and planned.

The need for Nazir coaching aims to realize the professional Nazir, which is working on the basis of the profession. Profession is work done as living livelihood by relying on high skills and skills and by involving deep personal moral (Depag, 2005: 70). There are several professional characteristics, among others, are: First, there are special skills and skills to be able to run a good job. These special skills and skills are generally held to the degree, scope, and level that has the expertise and skills that most others have. Second, high moral commitment. This moral commitment is usually set out in the form of special rules that become a guide for everyone who carries out the profession in question. Third, get paid or wages that are worth the work. Fourth, community service, even more prioritizing community interests than personal interests. Fifth, there is a special permit in carrying out his profession. Thus, Nazir professionals are managers who in managing waqf assets refer to the principles of modern management, who work seriously, discipline and are responsible (Ministry of Religion, 2005: 80).

In line with the above, according to Fatchurrahman Djamil Nazir the professional was intended to be Nazir who had met three criteria, as follows: First, moral criteria. In this case, Nazir professionals must understand the waqf law in sharia review and positive law. In addition, Nazir must also be honest, trustworthy, fair, temptable, emotionally and spiritually intelligent, and accept assignments as Nazir as a choice. Second, management criteria. Nazir prefesional must have Page | 111 
leadership, visionary, intellectual and social intelligence in empowering waqf, professionals in managing waqf, and having a clear work program. Third, business criteria. In this case, Nazir professionals must be entrepreneurial or entrepreneurial (Indonesian $W$ aqf Agency Bulletin (BWI) No. 3 of 20115). The author adds the fourth criterion of professional Nazir, namely that Nazir should be a full timer, not only as a side job which in reality now is only as part time work.

Furthermore, in its implementation, in order to be able to work professionally in managing waqf assets, Nazir must have very good abilities, namely:

1. Understand waqf law and legislation related to perwakafan problems. The law here is not only limited to waqf laws, but can also include agrarian laws, flats, banks and others related to waqf issues.

2. Understanding Islamic economics and its instruments. Waqf is one of the instruments in the Islamic economy and must also be managed in sharia. Therefore, Nazir should understand the rules of play in Islamic economics.

3. Understand the practices of representatives in various countries. Thus, Nazir is expected to make innovations in developing waqf assets.

4. Manage waqf finances in accordance with financial management standards. Especially if Nazir has directed the management of investment-based productive waqf.

5. Distribute the results of the management of waqf assets to the community in an economic empowerment scheme for the people.

6. Manage waqf assets, especially financially in a transparent and accountable manner (Indonesian Waqf Agency Bulletin, 2015: 5),

With such criteria, God willing, productive endowments will develop in Indonesia, and productive endowments can truly be an element of empowerment and economic development of the people.

\subsection{CONCLUSION}

As a conclusion in this investigation, it can be stated that the the needs of professionals Nazir in managing productive waqf in Indonesia is very important. Because, by managing waqf productively by Nazir who is a professional, it is hoped that it will develop well and its function as an instrument of economic development of the people will be increasingly clearly visible. Even so, the Nazir's professionals have not yet materialized as expected. Therefore, the obstacles to realizing the professional Nazir in the management of waqf must be immediately overcome, by way of intensive and continuous Nazir coaching, so that Nazir is a professional. Nazir's professional is intended to be: First, there are special skills and skills that exceed the average, to be able to carry out the work properly. Second, high moral commitment, in accordance with the specific rules that become the work guidelines concerned. In addition, be honest, trustworthy, fair, temptation, intelligent emotionally and spiritually, and accept assignments as Nazir as a choice. Third, get paid or wages that are worth the work. Fourth, prioritizing the interests of the community from personal interests. Fifth, there is a special permit in carrying out his profession. Sixth, management criteria, namely having leadership capacity, visionary, intellectual and social intelligence in empowering waqf, professionals in managing waqf, and having a clear work program. Seventh, business criteria, namely entrepreneurial or entrepreneurial spirit. Eighth, that Nazir should be a 
full timer, not only as a side job which in reality now is only as part time work. This kind of Nazir can develop productive endowments for the economic empowerment of the people.

\section{LIST OF REFERENCES}

Abdul Shukor, S., Johari, F., Abd Wahab, K., Kefeli@ Zulkefli, Z., Ahmad, N., Haji Alias, M.,... \& AbuHussin, M. F. (2018). Trust on awqaf institutions: evidence from Malaysia. Journal of Islamic Marketing.

Abdurrahman. (1979). Masalah Perwakafan Tanak Milik dan Kedudukan Tanah Wakaf di Negara Kita [The Problem of Owning Land Ownership and Position of Land of Waqf in Our Country]. Bandung: Alumni.

Abu Su’ud, M. (1997). Risalah fi Jawaz Waqf an-Nuqud. Beirut: Dar Ibn Hazm.

Al-Alabij, A. (2002). Perwakafan Tanah di Indonesia. Jakarta: Raja Grafindo Persada.

Al-Asqalani, Ibn Hajar. t.t. Bulugh al-Maram, Beirut: Dar al-Fikr.

Al-Fanjari, M.S. (1988). Al-Iqtishad al-Islami. Beirut: Dar al-Fikr.

Al-Ghamarawi, t.t. Siraj al-Wahhaj. Beirut: Dar al-Fikr.

Al-Marghinani, B.A.H. (2000). Al-Hidayah Syarh Bidayah al-Mubtadi. Beirut: Dar al-Kutub al-'Ilmiyah.

Az-Zuhaili, W. (1997). Al-Fiqh al-Islami wa Adillatuh. Suriah: Damsiq.

Basyir, A.A. (1987). Hukum Islam Tentang Wakaf, Ijarah, Syirkah, Bandung: PT. Al-Ma’arif.

Buletin Wakaf Badan Wakaf Indonesia No. 1, 2 dan 3, Tahun 2015.

Daud Ali, M. (1988). Sistem Ekonomi Islam: Zakat dan Wakaf, Jakarta: UI-Press.

Government regulations. (1977). No. 29 Tahun 1977 Tentang Perwakafan Tanah

Government regulations. (2006). No. 42 Tahun 2006 Tentang Pelaksaan Wakaf

Huda, M., Sudrajat, S., Kawangit, R.M., Teh, K.S.M., and Jalal, B. (2019). Strengthening divine values for self-regulation in religiosity: insights from Tawakkul (trust in God). International Journal of Ethics and Systems. DOI: 10.1108/IJOES-02-2018-0025.

Huda, M., Mulyadi, D., Hananto, A. L., Nor Muhamad, N. H., Mat Teh, K. S., \& Don, A. G. (2018). Empowering corporate social responsibility (CSR): insights from service learning. Social Responsibility Journal, 14(4), 875-894.

Ibrahim, D. (2008). Wakaf dalam Persepektif Fiqih dan Perundang-Undangan (Suatu Alternatif Pengentasan Kemiskinan. Palembang: Grafika Telendo Press.

Ministry of Religious Affair. (2000). Kumpulan Hasil seminar Perwakafan. Direktorat Pengembangan Zakat dan Wakaf.

Ministry of Religious Affair. (2005). Fiqih Wakaf, Direktorat Pengembangan Zakat dan Wakaf.

Ministry of Religious Affair. (2005). Pedoman Pengelolaan Wakaf Tunai, Direktorat Pengembangan Zakat dan Wakaf.

Ministry of Religious Affair. (2005). Proses Lhirnya Undang-Undang No. 1 Tahun 2004 Tentang Wakaf. Direktorat Pengembangan Zakat dan Wakaf.

Ministry of Religious Affair. (2005). Nazir Profesional dan Amanah. Direktorat Pengembangan Zakat dan Wakaf.

Ministry of Religious Affair. (2005). Paradigma Baru Wakaf di Indonesia. Direktorat Pengembangan Zakat dan Wakaf. 
Ministry of Religious Affair. (2005). Perkembangan Pengelolaan Wakaf di Indonesia, Direktorat Pengembangan Zakat dan Wakaf.

Qal'ah Ji, Muhammad Rawas. (2000). Mabahits fi al-Iqtishad al-Islami. Beirut: Dar an-Nahdhah al-'Arabiyah.

Sahlan, M. K., Abu-Hussin, M. F., \& Hehsan, A. (2018). Market coopetition: Implications of religious identity in creating value added partnership within halal mart retailers", Journal of Islamic Marketing, 10(2), 465-475. https://doi.org/10.1108/JIMA-04-2017-0046

Undang-Undang Pokok Agraria (UUPA) No. 5 Tahun 1960.

Undang-Undang Nomor 41 Tahun 2004 Tentang Wakaf. 